The third theme is that of the opposition between value pluralism and monism. This is the theme that has had the most impact upon political theorists since Berlin's death. Berlin himself did not produce a detailed account of just what he meant by value pluralism and it has been left to others to explore the nature and implications of this idea. He did not say much about the conceptual distinction between incomparability and incommensurability and was less than convincing upon the implications of value pluralism for practical reason. The thesis of pluralism has been accused of being no more than a version of relativism, while some of those who are sympathetic to the idea do not see it as being particularly original. Berlin reluctantly admitted to the existence of intellectual precursors such as Max Weber.

The most troubling problem, perhaps, for Berlin here was that of the relationship between pluralism and liberalism. Does pluralism entail or does it undermine liberalism?

Crowder makes a good case for placing Berlin within a particular intellectual and political context. Certainly, his liberal pluralism does not exactly produce a strong theoretical argument but it does produce a persuasive rhetoric against the search for political and moral perfection. One could argue that if pluralism is true, then one of its consequences is to effect a limit upon the pretensions of theory.

Why do so many, despite all the criticisms, still find Berlin so interesting? One reason is to be found in the contemporary recognition of what Rawls has called 'the fact of pluralism' as a serious problem. But, perhaps, more significantly Berlin represents a historically sensitive way of writing political theory that owes nothing to the abstracted utopianism of much recent normative theorizing while, at the same time, in taking the central vision of thinkers seriously, avoids the reductionism and superficiality of much political science.

Peter Lassman

Department of Political Science and International Studies, The University of Birmingham, UK

\title{
The Question of Women in Chinese Feminism
}

Tani E Barlow

Duke University Press, London, 2004, $x+484 p p$.

ISBN: 0822332701.

Contemporary Political Theory (2006) 5, 360-362. doi:10.1057/palgrave.cpt.9300246

The question of women in Chinese feminism is a superbly argued exercise in feminist historiography that analyses the Chinese feminist project of establishing and defining the subject of women in 20th century modern Chinese 
intellectual history. Barlow traces changing intellectual preoccupations with international eugenicist social theory, political discourse and literature in the establishment of Chinese progressive feminism specifically, and Chinese Enlightenment thought and modernity more generally. She argues that progressive feminism's concern with gender inequality and women's emancipation constitutes a key element and influence in the development of Chinese intellectual thought overall.

Barlow's achievement rests with her originally argued ambition to show the inherently necessary relationship between feminist theory and internationalist modernity projects, whether they are labelled colonialism or globalization, and the way she proposes to do this by developing a feminist analytical approach that reads history not as representations of what categories of subjects (women) existed at particular points in time, but what they will have been in the future - the future anterior. In other words, she rejects the biogenetic argument of knowing what women really are as a temporal social fact, that their representations in texts are all there really is to women as a social and sexual subject, and proposes instead a speculative, historical argument of what women as category must have been, a claim about women as future potential in respect of their female embodiment (p. 360). Such a reading transcends historiographic regimes' limiting and enabling of what we can say about subjects categorically, she argues, and successfully exemplifies her thesis by analysing key works by three prominent female writers and critics: Ding Ling, Li Xiaojiang and Dai Jinhua. Each are prominent figures in the establishment of feminist theory in modern China, and Barlow details how their work and participation in literary and political discourse reflect the intellectual struggles of establishing modern Enlightenment thought in China with the women subject as an indispendable analytical category.

In Ding Ling's 1920s and 1930s, and through the tumultuous revolutionary era when she was imprisoned, and finally rehabilitated in the late 1970s, Barlow's analysis of Ding Ling's fiction shows an urgent concern for the lack of 'social standing' of women in society, and details the expressions, especially erotic, of regretful instability in her fictional subjects, and ultimate call for future justice to come. In Li Xiaojiang's 1980s, feminist theory turned to critique the Maoist Revolution's politicized and masculinized gender project and advocated a natural sexual difference in which a postMaoist market increased commodification of social relations and economy a kind of market feminism - would eventually enable gender equality. Dai Jinhua's anti-essentialist écriture féminine chinoise focuses on the women category amidst rapid socio-economic transitions of post-socialist development and the increasing mass culture of consumption since the early 1990s.

Barlow masterly unravels how feminist and nationalist attempts to address gender inequality in Chinese society never was and could never be a Chinese 
project exclusively, whether in origin or development, as they were and still are premised on modernist evolutionary eugenicist theories of human sexual difference and heterosexual procreation. Tracing the inherently international nature of feminist and Enlightenment intellectual movement in modern China in this way, she shows the link between the development of such ideas and theories in Europe and Japan and the surfacing of a national tradition of feminism in China, still firmly placed within a contemporary globalized discourse seeking to stabilize modernist concepts of womanhood. This dynamics created the problem that theoretical projects ultimately simultaneously rest on and produce the analytical need for a categorically stabilized subject and frozen in time, but which in Barlow's challenging and original feminist historiographic re-reading, also enables future potential and aim of gender equality that unites feminist theory everywhere as a globalized project. The book thus provides the reader with a comprehensively detailed, yet highly readable, insight into Chinese modern history seen from a feminist angle.

The question of women in Chinese feminism should be of interest to anyone fascinated by the challenges an increasing globalized world poses to academic understanding and analysis in terms of the interrelationship between claims to universality and local knowledge regimes, as well as to those with particular interests in China and feminist theory.

\author{
Elisabeth Engebretsen \\ Department of Anthropology, \\ London School of Economics and \\ Political Science, UK
}

\author{
On Populist Reason \\ Ernesto Laclau \\ Verso, London, 2005, 76pp. \\ ISBN: 1859846513. \\ Populism and the Mirror of Democracy \\ Francisco Panizza (ed) \\ Verso, London, 2005, 358pp. \\ ISBN: 1859844898.
}

Contemporary Political Theory (2006) 5, 362-367. doi:10.1057/palgrave.cpt.9300255

One consequence of the so-called war against terror is that the line between 'left' and 'right' is ever more blurred. Opposition to the Iraq invasion, for 